\title{
Erotismo y belleza en la antigua cultura náhuatl: aproximaciones para su estudio
}

\author{
Miriam LóPEZ HERNÁNDEZ \\ Instituto de Investigaciones Estéticas, Universidad Nacional Autónoma de México \\ mirlop@yahoo.com
}

Recibido: $13 / 1 / 2015$

Aceptado: 10/6/2016

\section{RESUMEN}

El propósito del artículo es explorar los ámbitos del cuerpo, el erotismo y la belleza entre los antiguos nahuas. A través de la escultura antropomorfa, los textos etnohistóricos, las representaciones pictóricas y la lengua náhuatl, se reconstruyen las ideas estéticas y eróticas de la antigua cultura nahua. En el texto se consideran narrativas y descripciones que nos hablan del cuerpo erótico femenino y masculino: las caricias de las prostitutas a los ixiptlahuan de los dioses antes de morir, el galanteo en el cuicacalli entre los guerreros y las prostitutas; así como el uso del maquillaje, pintura y lenguaje corporal femeninos.

Palabras clave: Erotismo, belleza, sexualidad, cuerpo, nahuas, escultura.

\section{Eroticism and Beauty in the Ancient Nahua Culture: Approaches to their Study}

\section{ABSTRACT}

The purpose of this article is to explore the field of the body, the eroticism and the beauty among the ancient Nahuas. By means of the anthropomorphic sculpture, the ethnohistoric texts, pictorial representations and the Nahuatl language, esthetic and erotic ideas of the ancient Nahua culture are reconstructed. In the text are considered narratives and descriptions that refer of the erotic female and masculine body: the caresses of the prostitutes to the ixiptlahuan of the gods before dying, the courtship in the cuicacalli between warriors and prostitutes; as well as the use of feminine makeup, body painting and language.

Key words: Eroticism, beauty, sexuality, body, Nahuas, sculpture.

Sumario: 1. Introducción. 2. Escultura antropomorfa. 3. El cuerpo erótico. 4. Estética femenina. 5. El perfecto telpochtli: el cuerpo masculino y la identidad sexual. 6. El ixiptla de Tezcatlipoca. 7. Las esposas de Tezcatlipoca y el arreglo femenino. 8. Conclusiones. 9. Referencias bibliográficas.

\section{Introducción}

Georges Bataille (1979: 23) y Francesco Alberoni (2006) han demostrado que el erotismo debe ser diferenciado de la realidad sexual, pues éste se desvía del vínculo reproductivo y del cuidado de los hijos. En este caso, lo que se busca no son las expresiones externas únicamente, sino también la experiencia subjetiva y el significado cultural dado a ella. Así, aunque el erotismo por definición es una actividad humana relacionada con la función sexual, ésta es elevada al plano del significado, el cual es aportado socialmente por la cultura en la cual se presenta.

En este artículo se entiende por erotismo aquella construcción cultural ligada a la sexualidad, al género y al cuerpo. Es un complejo de símbolos que forma parte fundamental de la sexualidad de cada cultura y sus características específicas dependen del grupo humano de estudio.

Francesco Alberoni (2006) ha señalado que el erotismo es una forma de conocimiento, el del cuerpo. Así el cuerpo es el medio para conocer el erotismo de una 
cultura, en él se expresan físicamente las sensualidades; en su adorno, postura, descripción -mediante la poesía o metáforas- se encuentran los significados del goce, el placer y las fantasías del grupo en cuestión.

En el estudio de las culturas prehispánicas únicamente tenemos a nuestra disposición la huella que han dejado los antiguos mesoamericanos en sus representaciones escultóricas, pictóricas y en distintos tipos de documentos, registros de los que echaré mano para develar este aspecto poco conocido de la cultura nahua ${ }^{1}$.

\section{Escultura antropomorfa}

El cuerpo, al ser el ámbito mejor conocido por el humano, es el tema más representado en el arte y en la escultura. Entre los antiguos nahuas esto es incuestionable. A través de la escultura antropomorfa mexica podemos ver las formas en las que este pueblo abordó su propia corporeidad y el modo en que proyectó visualmente sus cánones de belleza y cosmovisión; de manera particular, mi interés será la ideología sexual.

La escultura fue un medio de expresión de gran importancia en esta cultura, lo que puede advertirse en el número de piezas que han llegado hasta nosotros a pesar de la destrucción sistemática de que fueron objeto durante la Conquista. Su majestuosidad en cuanto a tamaño, maestría en la técnica y ubicación dentro de la ciudad, las señalan como vehículos predilectos de su ideología (Aguilera 1977: 11).

Solís (1985: 428) atinadamente opina que en las esculturas antropomorfas puede identificarse la imagen del «perfecto ciudadano», parte integrante del orden cósmico, a la par de ser un poderoso transmisor de las normas de conducta. Por otra parte, señala Aguilera (1977: 12) que la significación social del arte es más importante que su estética ${ }^{2}$ en el espectador de la propia cultura, pues las manifestaciones plásticas cargan un simbolismo particular en su ámbito social. De esta manera, el estudio del arte es un medio para acercarnos a la ideología dominante. Pero es imperativo en el análisis que se conozca el contexto cultural de las obras en cuestión, pues el fin último es entender una cultura, estudiar un ámbito dentro de esa sociedad, en este caso, su pensamiento respecto a la sexualidad, erotismo y belleza.

La tradición escultórica azteca creó imágenes de hombres y mujeres que desempeñaron diversos roles como guerreros, sacerdotes, dioses, gobernantes y gente común (Solís 1991: 76). Existe una básica separación, atendiendo al sexo de las figuras representadas. Así, puede observarse que se encuentran perfectamente diferenciadas las femeninas de las masculinas por su vestimenta, atavíos y ornamentos, además de por las posturas (Solís 1985: 424).

Los ideales femeninos y masculinos no son universales, pues son construcciones de una cultura y época específicos, de manera que van cambiando a lo largo del tiem-

\footnotetext{
1 En el artículo se ha normalizado la ortografía del náhuatl de acuerdo con las normas del GDN (Gran Diccionario Náhuatl).

2 El término estética se emplea en el presente texto con varias acepciones: 1) ciencia que trata de la belleza y de la teoría fundamental y filosófica del arte; 2) conjunto de elementos estilísticos y temáticos que caracterizan al arte, en este caso, nahua; 3) adjetivo que es sinónimo de bello y 4) relativo a la percepción o apreciación de la belleza (Real Academia Española 2014: sub voce estética).
} 
po. En el estudio de la plástica mexica observaremos que los patrones responden a conceptos que tenían los nahuas de la condición humana y a los estereotipos sexuales.

\section{El cuerpo erótico}

La cuestión estética-erótica es relativa. Cada cultura tiene sus propios códigos y el erotismo y la belleza como un valor responden a éstos. En el periodo Preclásico existió un gusto por representar a las mujeres con amplias caderas, llamadas por los arqueólogos «pretty ladies», estilo que se ha relacionado con un culto a la fertilidad y exaltación de la capacidad reproductora femenina.

Estas figurillas de las «mujeres bonitas» son lo más representativo de la cerámica de Tlatilco, sitio preclásico a orillas del lago de Texcoco. Su modelado es eminentemente frontal. Son mujeres púberes con torso acinturado, caderas muy anchas, piernas redondeadas y los muslos extremadamente gruesos que se han denominado con «forma de cebolla». Presentan senos pequeños con el círculo del pezón destacado; el ombligo se muestra profundo, ancho y redondo. Las extremidades son secundarias en las figurillas; cuando se muestra la curva completa del brazo, las manos se sitúan encima de los senos, en el vientre, las caderas o en la vulva. Cuando aparecen con falda, su «sexo queda indicado por la juntura marcada de las piernas» (Solares 2007: 140-141).

Las singularidades de sus cuerpos y la abundancia de estas representaciones escultóricas denotan la importancia que tenía para los antiguos pueblos agrícolas de la cuenca de México la reproducción de la naturaleza, por ello el acento en su desnudez y en sus estados de embarazo.

Esta predilección por mujeres con caderas muy pronunciadas aparece nuevamente en el periodo Posclásico, pero como objeto de deseo. Dichas formas pasaron de ser símbolos de la fertilidad a ser anheladas como cuerpos de placer y formaron parte del universo erótico de los antiguos pobladores del centro de México.

El erotismo lleva a una búsqueda del objeto de placer; al respecto mencionaré tres relatos. Refiere la Historia tolteca-chichimeca (1989: f2r, párr. 19, 133; Garibay 2000: 467) que Huemac sostuvo una guerra contra los nonoalcas porque su exigencia de mujeres no fue cumplida según sus deseos:

«Entonces les pide mujeres. Dice a los nonoalcas:

- Tenéis que darme tributo de mujeres. Yo os mando que sean de caderas anchas de cuatro jemes $[\ldots]$

Luego le vienen a ofrecer cuatro mujeres. Pero él no las aceptó en su tamaño: ¡no dan la medida que él pide! Ya dice a los nonoalcas:

- No es todo lo que yo quiero: no llegan a cuatro jemes. ¡Muy grandes las quiero!»

En otra narración, la extrema delgadez de la esposa de Moquihuix, tlatoani de Tlatelolco, fue una de las causas de la guerra de 1473 entre las ciudades gemelas. Aunque seguramente la rivalidad de los gobernantes y otros asuntos políticos fueron causales de la batalla, la vida sexual del gobernante y sus problemas maritales han sido destacados en distintas fuentes.

En la Crónica Mexicayotl se dice que Moquihuix repudiaba a su esposa principal llamada Chalchiuhnenetzin, hermana mayor de Axayacatl, tlatoani de Tenochtitlan, 
pues no podía aguantar la fetidez de su aliento, además de que «no la estimaba en nada por ser deleznable, de feo rostro, delgaducha y sin carnes, y la despojaba de cuanta manta de algodón le enviaba Axayacatzin, su hermano menor, dándoselas a sus mancebos». No quería dormir el tlatoani con ella porque tenía el pecho muy huesudo. Dicho desprecio enojó a Axayacatl y le declaró la guerra a Tlatelolco (Alvarado Tezozomoc 1998: 117).

Algunos relatos critican el comportamiento del soberano de Tlatelolco con sus mujeres, pues las hacía engordar hasta que alcanzaran unas caderas enormes (Anales de Cuauhtitlan 1992: 113).

Por otra parte, se narra que un día la hija de Huemac, soberano de Tula, vio a Tohueyo vender ají en el mercado, pero sin maxtlatl, lo cual provocó que se le antojara su pene (Florentine Codex 1950-1982: lib. III, cap. V, 19). Debido a ese deseo sexual cayó enferma, «hinchósele todo el cuerpo». Huémac preguntó a las mujeres que la guardaban: «¿Qué mal tiene mi hija?», ellas le respondieron que era por haber visto el genital de aquel Tohueyo.

En seguida, Huemac mandó que le trajeran al Tohueyo y le preguntó por qué no usaba maxtlatl y no se cubría con la manta, a lo que respondió que en su tierra guardaban la costumbre de andar desnudos. Huemac le reveló: «Vos antojastes a mi hija, vos la habéis de sanar». El Tohueyo se resiste, pero Huemac lo amenaza: «Por fuerza habéis de sanar a mi hija, no tengáis miedo». Justamente, al entrar el Tohueyo al aposento de la hija y dormir con ella, la cura (Sahagún 2002: t. I, lib. III, cap. V, 312-313; León-Portilla 1959: 101-105). Es así que la enfermedad y el desequilibrio únicamente se sanarían y restaurarían dándole satisfacción al deseo.

Entre los antiguos nahuas, la sexualidad en principio fue pensada como una actividad placentera, como un acto erótico más que reproductivo. Les fue dada a los humanos para paliar las tristezas y sufrimientos de este mundo. En las prédicas que les dirigían a las jóvenes nobles cuando llegaban a la edad de discreción, observamos que se referían a los ámbitos de la sexualidad con el término tlalticpacayotl, lo que se encuentra sobre la superficie de la Tierra, «lo terrenal», el acto sexual.

«Oye bien, hija mía, niña mía: no es un lugar agradable la Tierra; no hay contento, no hay alegría. Se dice que sólo hay alegría con cansancio, alegría con aflicción sobre la Tierra. Así lo andan diciendo los viejos: para que no estemos viviendo en lloros por siempre, para que no fenezcamos de tristeza los hombres, él, Nuestro Señor, se dignó darnos la risa, el sueño y nuestro sustento, nuestra fuerza, nuestro brío. Y esto más: lo terrenal [el sexo], para que sea la reproducción» (Florentine Codex 1950-1982: lib. VI, cap. XVIII, 93, traducción de López Austin 1996 [1980]: II, 276).

Destaca en estos discursos la concepción de que la vida está llena de sufrimientos: hambre, sed, trabajo físico, cansancio. Para aliviar el dolor, los dioses han dado placeres, entre ellos el más grande es el sexual.

\section{Estética femenina}

El modelo de cuerpo y las proporciones deseables cambian a lo largo del tiempo, de cultura en cultura y dentro de la misma sociedad. Inclusive puede advertirse la 
convivencia de dos tipos de cuerpos deseables y estéticos en la cultura nahua. A partir de distintos registros, en especial de la escultura, podemos notar que un código estético en la época mexica era que las mujeres fueran delgadas pero no en demasía, sus pechos se muestran pequeños y sin caderas anchas.

Una digna representante de este ideal de belleza es la Venus de Texcoco (Figura 1). Este modelo único representa a una mujer completamente desnuda. Está trabajado con gran detalle y de manera realista. Es un cuerpo adolescente con pechos todavía en crecimiento, los cuales no se destacan de ninguna manera. Su sexo y bajo vientre están marcados mediante volumen de la roca. La cintura está tallada finamente y los muslos y pantorrillas se presentan redondeados.

El rostro es inexpresivo, parece portar una máscara. En el centro del torso se encuentra una cavidad rectangular en la que se alojaba el corazón de piedra verde. La cabeza tiene perforaciones en donde seguramente se le insertaban mechones de cabello humano, lo cual haría más realista la representación. Es probable que también tuviera en los ojos y boca incrustaciones de concha y otros materiales.

Otra figura de excepcional belleza es la estatuilla de madera conocida como «Diosa de Coatepec Harinas», recientemente bautizada como «La Señora de Chalma» (López y Filloy 2012) (Figura 2). Debido a que los objetos de madera difícilmente se conservan con el paso del tiempo, contamos con pocos ejemplares de estas representaciones llamadas cuauhximalli, las cuales es seguro que fueron abundantes y de fácil transporte por su menor peso en comparación con las de piedra.

La representación tallada en madera rojiza

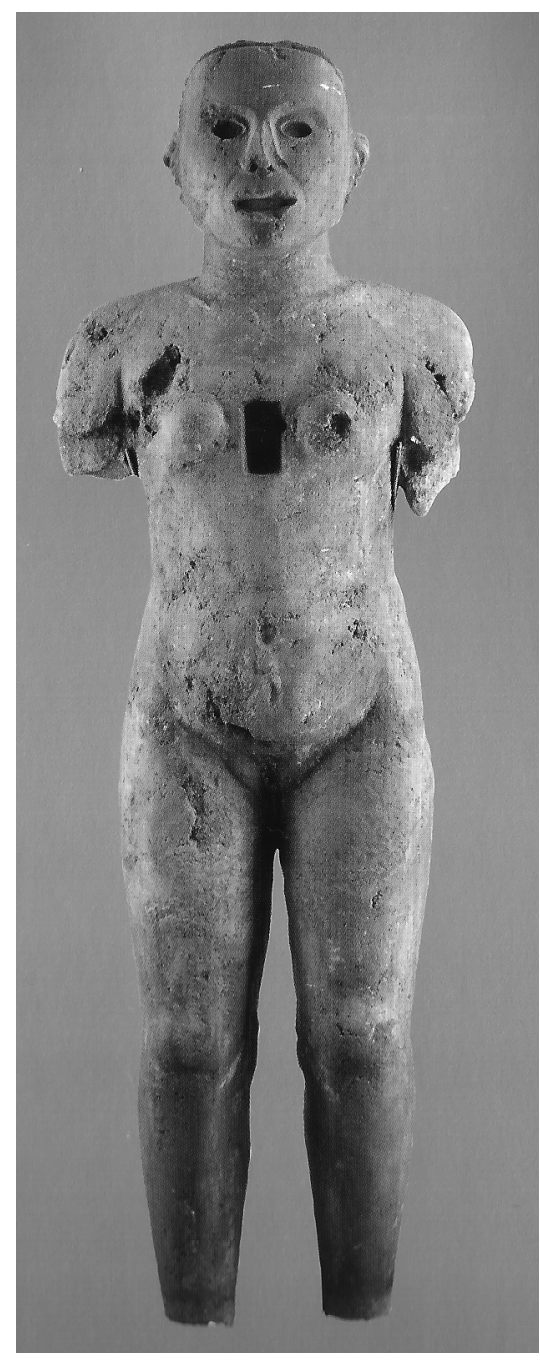

Figura 1: Venus de Texcoco. Museo Nacional de Antropología (tomada de El Imperio Azteca 2004: 107, fig. 130). sostiene sus pechos con ambas manos exaltando su cualidad nutricia. Las piernas y las caderas están ocultas bajo un enredo sin faja que llega hasta los tobillos. Tiene su cabello entrelazado encima de la cabeza y de la frente. En opinión de López y Filloy (2012: 77), el peinado recuerda al petob huasteco. Su rostro aún conserva las incrustaciones de concha en los ojos y dientes.

La figura fue encontrada en el Cerro del Tambor al sur del Estado de México, entre los pueblos de Ocuilan y Chalma. Mide $39,5 \mathrm{~cm}$ de alto, $15 \mathrm{~cm}$ de ancho y $10 \mathrm{~cm}$ de 


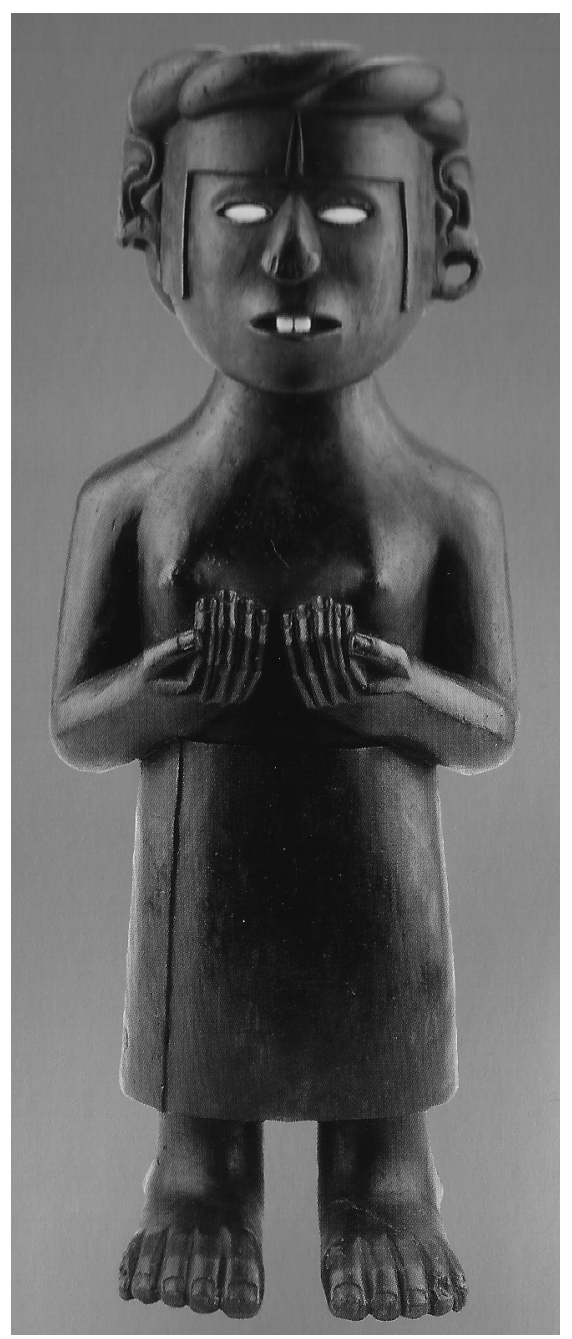

Figura 2: La Señora de Chalma (Diosa de Coatepec Harinas). Museo Nacional de Antropología (El Imperio Azteca 2004: 107, fig. 133).

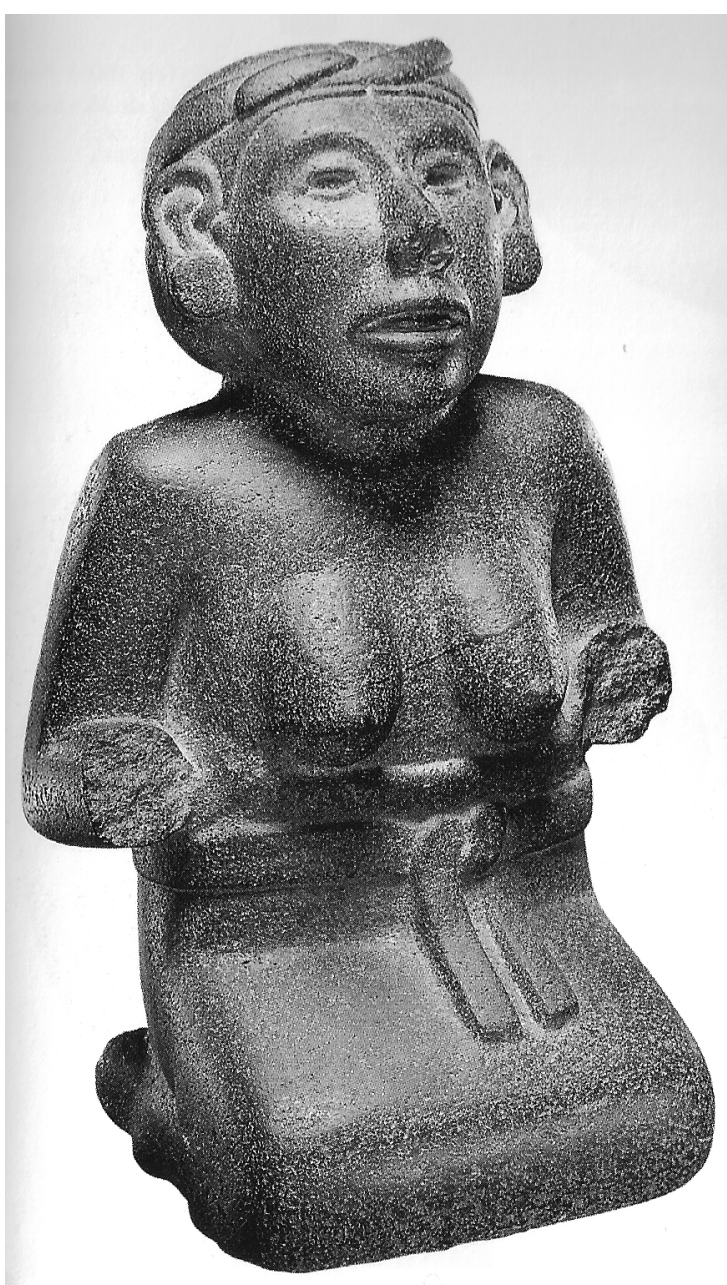

Figura 3: Mujer arrodillada. American Museum of Natural History, Nueva York (Arqueología Mexicana, Edición Especial 13: 23).

espesor, mientras que su peso es de 1,2 kg (López y Filloy 2012: 72). Esta mujer de cuerpo joven, senos pequeños y cara serena representa el canon estético de la escuela mexica y, en particular, de las diosas de los mantenimientos, con un claro énfasis en su torso desnudo que presenta sus senos como una ofrenda.

Respecto al desnudo femenino, la figura de una mujer de rodillas que se encuentra en el Museum für Volkerkunde de Leipzing destaca por ser un desnudo completo, mientras cubre su sexo con las manos. Gendrop y Díaz (1994: 150) mencionan que posiblemente es un gesto de «castidad» acorde con el ideal de comportamiento de la 
mujer mexica. Los senos se muestran flácidos, es pues una mujer que ha amamantado. La porosidad de la roca induce a pensar que la figura representada es la de una anciana.

La desnudez de estas figuras va en el sentido de fertilidad o de exaltación de su cualidad reproductora. Recordemos que las mujeres mexicas se vestían con un cueitl $^{3}$, un huipilli (camisola sin mangas) y, ocasionalmente, un quechquemitl (pequeña capa triangular); a diferencia de las mujeres huastecas, quienes comúnmente llevaban al descubierto los pechos y se los cubrían con un quechquemitl en algunas ceremonias (Stresser-Péan 1971: 590-591).

Una escultura más, pero de una joven, es la que se conserva en el American Museum of Natural History de Nueva York. Se presenta en una postura común de las mujeres: arrodillada. Al igual que las piezas descritas con anterioridad, no tiene atributos específicos que nos permitan identificarla con una divinidad. Está tallada en un bloque de basalto y finamente pulida (Figura 3).

Destacan los senos meticulosamente modelados, detallados al punto de esculpir los pezones, al igual que en la estatuilla de «La Señora de Chalma». Porta una sencilla falda, su rostro es sereno y parece encarnar el ideal de comportamiento femenino. Se esperaba que fueran mansas, pacíficas, humildes, que practicaran la castidad, la honradez. Se les pedía que fueran consideradas y discretas, siempre atentas y solícitas a los deseos de los demás sirviéndolos, humillándose y respetando a todos (Sahagún 2002: t. II, lib. X, cap. XIII-XV, 884-892).

Desde pequeñas se les inculcaban las buenas costumbres en materia sexual: «Nunca te has de acordar, ni ha de llegar a tu corazón, ni jamás has de revolver dentro de ti cosa ninguna carnal [...] has de hacer fuerza a tu corazón y a tu cuerpo para olvidar y echar lejos de ti toda delectación carnal» (Sahagún 2002: t. II, lib. VI, cap. XL, 656; Florentine Codex 1950-1982: lib. VI, cap. XL, 217).

Volviendo a la escultura descrita, es del pueblo de Iztapalapa, en la ribera sur del lago de Texcoco. Se piensa que personifica a una diosa del maíz, posiblemente Chicomecoatl, quien se caracterizaba como una adolescente (Solís 2004: fig. 125). Beatriz de la Fuente (2004: 44) señala que en la escultura mexica las mujeres representadas «siempre son diosas, nunca humanas. La condición femenina no importa excepto en su calidad sagrada: la Gran Madre en incontables variaciones».

La mayoría de las mujeres esculpidas son jóvenes, están hincadas y descansan el cuerpo sobre las rodillas y pies. La misma autora indica que: «son escasas las que se atreven a desnudarse, siquiera el torso. Esa tímida desnudez las asocia con Xochiquetzal: muestran los pechos al aire y adornan su cabeza con guirnaldas de flores» (Fuente 2004: 44).

Igualmente, se considera que en el arte oficial se exalta a las jóvenes matronas, «símbolo de la fertilidad de la especie, equivalente a la fuerza reproductiva de la naturaleza» (Solís 2004: 102).

Como hemos visto, los senos representados en la escultura son modestos, no buscan ser eróticos, sino más bien enfatizar los ámbitos de acción de las diosas vincu-

3 Falda sin costura, de una pieza recta que ajustaban a la cintura mediante un ceñidor o faja y que llegaba hasta la pantorrilla. 
lados con la fertilidad, los mantenimientos. Quizás estaban demasiado identificados con la lactancia (Clendinnen 1998: 258).

Cabe señalar que los senos grandes eran mal vistos y estaban relacionados con hábitos alimenticios reprobados. A las mujeres con esta característica se les llamaba tlacazolchichihuale (Molina 2004 [2]: f115r) ${ }^{4}$. El término tlacazolli (Molina 2004 [1]: f65v) está compuesto por la palabra tlacatl, persona, la desinencia zolli, la cual indica el despectivo «ucho», por lo que puede traducirse como «personucha» o «persona de desperdicio» ${ }^{5}$; y el término chichihual, seno. En este sentido, podemos apreciar la carga peyorativa que les daban a estas mujeres pues eran «poseedoras de senos glotones».

Como mencioné líneas atrás, una característica común es la esbeltez de las imágenes, la deseable figura femenina era delgada, aunque no en extremo. En una escena que seguramente fue frecuente, una madre exhorta a su hija a mantenerse en forma, a tener una figura esbelta: «salta para que no seas gorda, una inflada» (Florentine Codex 1950-1982: lib. VI, cap. XIX, 100).

Así puede observarse la imagen ideal de la mujer que muestran las representaciones escultóricas en cuanto a su actitud y modestia, y también a su complexión e ideal de belleza. Estas representaciones se elaboraron con el fin de exaltar y reproducir ciertos modelos estéticos y comportamentales. Resulta evidente que, entre los antiguos nahuas, la noción de belleza venía acompañada de virtud, la virtud encerraba belleza y viceversa. De manera que un rasgo notable en una persona virtuosa era su hermosura.

\section{El perfecto telpochtli ${ }^{6}$ : el cuerpo masculino y la identidad sexual}

La forma de representar la desnudez en el arte responde a un sistema de convenciones artísticas reinantes en determinado periodo histórico, el cual expresa construcciones culturales y simbólicas. Ello contempla las relaciones entre los símbolos y también las relaciones sociales; incluye las concepciones respecto al prestigio, estatus, género y poder del grupo en cuestión.

Los desnudos representados son cuerpos despojados de la indumentaria esencial requerida por el pudor de una sociedad específica. En contraste con la desnudez común, la artística no es vergonzosa ni incómoda. El cuerpo desnudo se muestra orgulloso, seguro, digno, en equilibrio y exalta, en muchos casos, el ideal de belleza de dicha cultura ${ }^{7}$. Además es erótico, es deseable, tanto el del hombre como el de la mujer. Sin embargo, entre los mexicas existe una predilección por el cuerpo varonil. El desnudo masculino se presenta en su forma humana, a diferencia del femenino que sólo aparece en su faceta divina.

\footnotetext{
4 Siguiendo la propuesta del Gran Diccionario Náhuatl (GDN), se utilizan las abreviaturas [2] para la sección náhuatl-español del Vocabulario... de Molina, y [1] para la sección español-náhuatl.

5 En opinión de Pablo Escalante Gonzalbo, octubre 2008, comunicación personal.

6 Joven.

7 Cabe señalar que existen ejemplos de esculturas mexicas en donde el cuerpo representado no es el ideal estético, véase el anciano en Arqueología Mexicana. Edición Especial 13: 22.
} 
En el arte azteca existen figuras antropomorfas llenas de atavíos e indumentaria y con signos asociados que nos permiten identificarlas; otras más presentan una completa desnudez, la cual muy probablemente era cubierta con vestidos de materiales perecederos.

Casi todas las esculturas masculinas son jóvenes. Hay una exaltación del cuerpo varonil que tiene un carácter noble, valiente. En opinión de Solís (1991: 78) este gusto por plasmar la juventud se debió a que «el desarrollo histórico de la cultura azteca fue de corto tiempo 200 años en cuanto a su existencia oficial, de los cuales sólo cien serían de dominio y esplendor»; por ello, se buscaba plasmar «hombres jóvenes, vigorosos, con actitud de dominio pleno ante la vida» (Figura 4).

El periodo de transición de la niñez a la adultez quedó ampliamente representado en la plástica mexica. Contamos con distintas esculturas varoniles con edades que oscilan entre los quince y veinte años, tiempo en el que los jóvenes dejaban a sus familias para ingresar a las escuelas estatales y al salir de ellas se volvían ciudadanos (El Imperio Azteca 2004: s/p, ficha 131).

Asimismo, en esta etapa los hombres asumían la completa responsabilidad de sus vidas, formaban sus familias y se convertían en el sostén de la sociedad. En esa edad unos se convertían en agricultores, otros en artesanos, algunos más en guerreros y una minoría en funcionarios públicos.

Este conjunto de piezas sigue ciertas convenciones. Presentan los ojos almendrados y la boca entreabierta, en ocasiones en estas tallas aún pueden observarse restos de incrustaciones de concha y obsidiana que conformaban los ojos y de concha que simulaban los dientes. Tienen la nariz recta, de alas anchas y los labios son delgados. «Por lo común no muestran emociones ni actitudes definidas, se les aprecia distantes de la realidad. Conviene recordar que tal impresión se debe a que la piedra está desnuda, han desaparecido pintura, atavíos de materiales perecederos, cabellos y tocados»» (Fuente 2004: 44-46).

Como indiqué anteriormente, la representación del cuerpo varonil es casi la de un cuerpo adolescente, sin rasgos de musculatura, su rostro es joven. Se presentan desnudos, algunos ejemplares visten un maxtlatl «prenda propia de la masculinidad» (Solís 2004: 102). El taparrabo deja ver los glúteos, los cuales se presentan redondea- 


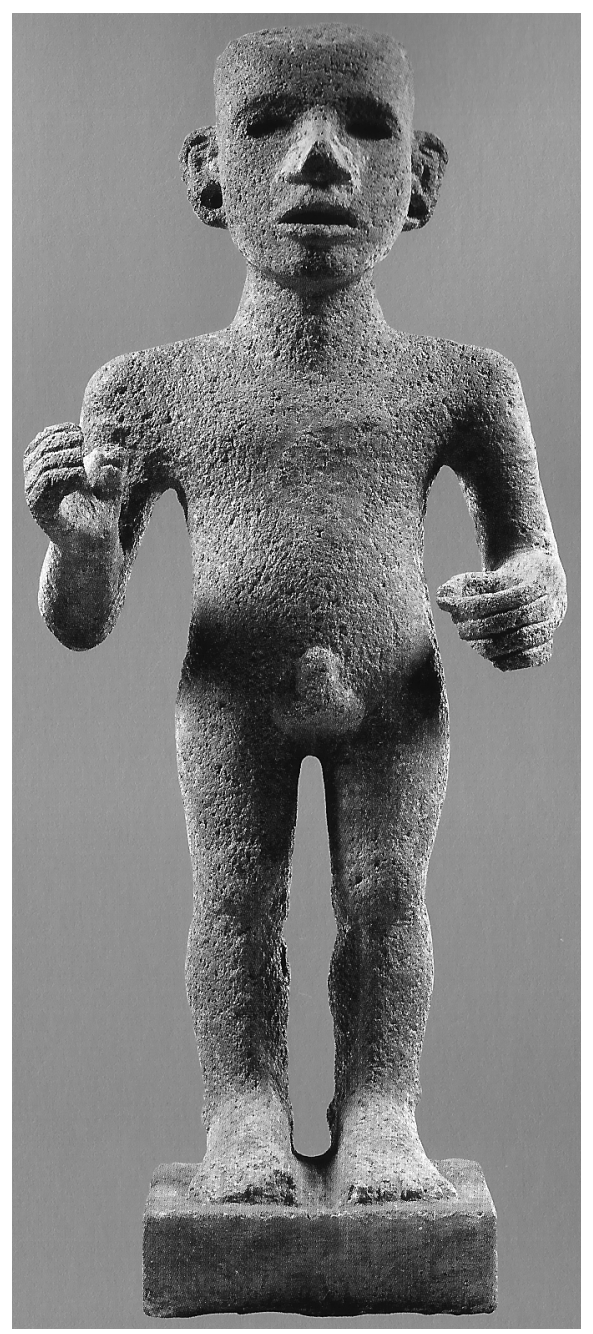

Figura 5: Joven, Texcoco. Museo Nacional de Antropología (El Imperio Azteca 2004: 107, fig. 131).

dos suavemente y no se marca la separación de los mismos.

Este grupo de esculturas se ha llamado de macehuales, aunque es indudable el origen humilde de los hombres representados que contrasta con los ornamentos de otras figuras (Solís 1991: 81), propongo denominarlos representaciones de telpopochtin, pues de esta manera se apela con mayor exactitud a lo que se desea destacar, la juventud, el ideal masculino.

Destaca en este conjunto la escultura de un joven desnudo con erección. Esta proviene de Texcoco en el Estado de México y, aunque pudo haber estado vestida, es claro que se buscó destacar su pene (Figura 5). Así, capturado en el tiempo y ante nuestros ojos se muestra el transitorio estado de erección. Los testículos, igualmente notorios, están tallados.

Este joven rompe con lo común de la plástica mexica que es ocultar los genitales bajo el maxtlatl o la falda. Sin embargo, al considerar en conjunto las esculturas de telpopochtin y de frente, puede observarse que en todas, en primer lugar, destaca el rostro y después la parte media del cuerpo, ya sea el maxtlatl o los genitales.

En este sentido, opino que el maxtlatl pudo haber tenido una función y simbología similar a la que actualmente se le da a la corbata, símbolo sexual y de la masculinidad, aparte de la obvia de vestir la parte media del cuerpo. En los telpopochtin el taparrabos, en lugar de ocultar, acentúa la parte genital del cuerpo de los varones y los extremos del braguero hacen un juego que parece alargar el pene.

Esta misma idea la observo en la lámina 59 del Códice Borgia (1993) (Figura 6). Vemos en el centro a un sacerdote [tlamacazqui] con el cuerpo retorcido. Su taparrabos puede tener varias interpretaciones, o bien la punta de su braguero está sustituida por la larga cola de un coralillo rojo (Seler 1980: t. II, 167) o bien su erección convierte a su miembro en una serpiente.

Justamente el término telpochtli (hombre joven), con el que denomino a este conjunto de piezas, también designaba al dios Tezcatlipoca (Florentine Codex 19501982: lib. II, cap. XXXI, 127; lib. XII, cap. XIII, 34), tema que nos permitirá profun- 


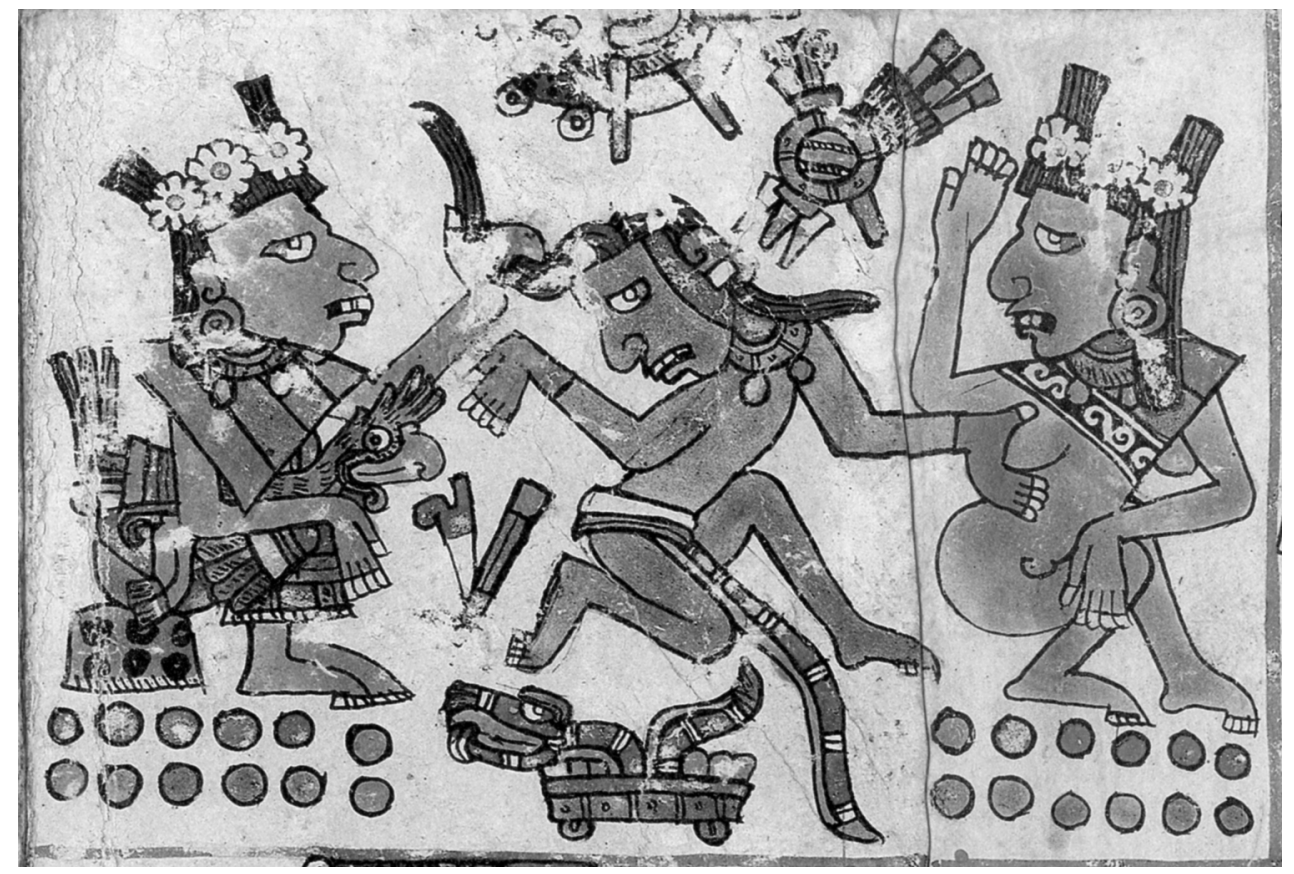

Figura 6: Un sacerdote [tlamacazqui] entre su esposa (izq.) y su amante (dcha.) (Códice Borgia 1993: lám. 59).

dizar en la perfección masculina. Reflexionaré a continuación en el representante del dios en la fiesta de Toxcatl.

\section{El ixiptla de Tezcatlipoca}

Durante el mes de Toxcatl se celebraba a Tezcatlipoca ${ }^{8}$. El ixiptla del dios era un joven que poseía características físicas notables. Su belleza es destacada en las descripciones que proporcionaron los informantes de Sahagún. La importancia de su cuerpo perfecto ocupa una cantidad considerable de texto en comparación con otros personificadores de dioses. A lo largo del año, se preparaba a este joven para representar al dios pues, además de contar con un físico perfecto, debía de saberse expresar correctamente, tener una entonación adecuada, cierto volumen y estilo. Recordemos que no se le consideraba un actor, sino que el dios estaba en él. Era la imagen del dios $\mathrm{y}$, como tal, usaba sus atavíos y su pintura? .

Encarnaba el ideal juvenil en cuanto a belleza física e inteligencia. Era escogido entre los cautivos de guerra ${ }^{10} \mathrm{y}$ durante un año era entrenado en diferentes artes: can-

\footnotetext{
8 Un estudio completo del dios y sus ámbitos de acción puede leerse en Olivier 2004a.

9 El concepto de ixiptla puede conocerse más ampliamente en López Austin 1998: 119-121.

10 Algunos autores opinan que era un esclavo. Referencias en torno a la identidad del ixiptla pueden leerse en Olivier 2002a: nota 15.
} 
to, música, oratoria; también debía saber portar y oler flores, fumar cañas de humo y comportarse elegantemente. A lo largo de esos meses vivía con lujos y era tratado como el dios mismo.

El representante del dios caminaba por las calles tocando la flauta, fumando y oliendo flores. La gente que lo veía se inclinaba ante él y tomaba tierra del suelo con el dedo y la chupaba como signo de respeto. Los hombres le pedían que les diera la victoria en el campo de batalla y buena fortuna para atrapar muchos cautivos (Durán 1967: t. I, cap. IV, 39-40).

No se menciona su proveniencia ni su clase social, pero Olivier (2002a: 113, 2004a: 366) considera que debía de ser noble pues era un requerimiento ineludible el que hablara correctamente el náhuatl, capacidad aprendida en una escuela como el calmecac. Es probable que, cómo en el caso de la ciudad de Texcoco, el ixiptla fuera un guerrero valiente de Tlaxcala o Huexotzingo [...] (Pomar 2000: 160, párr. 47). En contraparte, Toriz (2011: 221) opina que seguramente era un estudiante del telpochcalli, pues Tezcatlipoca era el dios patrono de este centro educativo.

Por otra parte, oler las flores y fumar era un privilegio, una distinción de clase (López Austin 1996 [1980]: I, 453). En los banquetes y fiestas, los señores acostumbraban traer flores en la mano juntamente con una caña de humo que iban chupando (Sahagún 2002: t. II, lib. VIII, cap. VII, 818).

La rigurosa preparación del ixiptla hacía que «aun en situaciones espontáneas o de aparente improvisación, supiera a la perfección la acción a ejecutar, ya fuera el saludar cordialmente, conversar con gracia, pronunciar con prudencia un discurso, dictar una orden, o corresponder adecuadamente a las muestras de humildad y reverencia» (Toriz 2011: 232).

El joven que representaba al dios se escogía cuidadosamente. Los informantes de Sahagún nos proporcionan una lista de las características deseadas enfatizando lo que no debía de poseer. Se le exigía un cuerpo perfecto [cualli inacayo]. Que fuera de buen semblante [cualli itlachieliz], inteligente [in mimatqui], sabio [in mimatini], de cuerpo limpio [in chipahuac inacayo], delgado como una caña [cuillotic, acatic], largo y esbelto como un bambú [piaztic, iuhquin otlatl], como una columna de piedra por todas partes [ipanoca temimiltic], no con cuerpo glotón [amo tlacazolnacayo], no gordo [amo tomahuac], no chaparro [amo no tetepiton], no muy alto [amo no cenca quauhtic] (Florentine Codex 1950-1982: lib. II, cap. VI [XXIV], 66).

Aquel que era escogido como ixiptla era intachable, sin defecto [atle yiayoca]. En la descripción el acento se pone en distintas partes del cuerpo. Respecto a su piel, ésta debía ser tersa como un jitomate o guijarro, es decir, sin manchas. Debía verse lisa, como si el joven hubiese sido tallado en madera [iuhquin tlachictli, iuhquin tomatl, iuhquin telolotli, iuhquin, cuahuitl tlaxixintli]. Su cabello no debía ser crespo [amo cuacocototztic] tampoco rizado [cuacolochtic] ${ }^{11}$; se deseaba que fuera lacio y largo [huel tzonmelahuac, tzompiaztic].

De su frente se requería que no tuviera protuberancias [amo ixcuatotomonqui], su cabeza debía ser redonda no abollada [amo cuapatztic], que no tuviera la cabeza

11 El cabello crespo o chino se relacionaba con ámbitos como la inmoralidad, la desgracia, el estado perturbado, la muerte y el inframundo, véase Piho 1973: 261-280 y López 2013: 163-185. 
grande [amo cuapatlachtic, amo cuahuacaltic], ni los párpados hinchados [amo ixcuatolpopozactic], sin los cachetes inflados [amo campoponaztic], no de cara larga y aplastada [amo ixpechtic], no de nariz aplastada [amo yacapatztic], no de fosas nasales anchas [amo yacacocoyactic], no de nariz cóncava [amo yacacaxtic], no de nariz aguileña [amo yacachittoltic], debía de tenerla derecha y larga [yacapiaztic].

No de labios gruesos [tenxipaltotomahuac], tampoco tartamudo [amono eltzatzacqui], que no hablara un lenguaje bárbaro/extraño [amo popoloc], no debía tener los dientes grandes [tlampantic], no ser dentudo [tlancuicuitztic], no tener los ojos redondos [amo ixtotolontic], ni muy hundidos [amo ixtacaltic], no tener el cuello cubierto con cicatrices [amo quechtitiquiltic].

Tampoco se deseaba que fuera orejón [amo no nacazpatlactic], que no tuviera los brazos muy largos [amo mahuihuitlatztic], que no fuera manco [amo matzicoltic, amo macuecuetzin], que no tuviera los dedos gordos [amo mapiltotomactic], que no fuera panzón [amo cuitlatoltic], que no fuera barrigón [amo cuitlapetztic], que no tuviera el ombligo prominente [amo xicquizqui], que no tuviera el trasero flácido [amo tzincuecuexactic], que no tuviera las nalgas flácidas [amo tzintamalcuecuexac] (Florentine Codex 1950-1982: lib. II, cap. VI [XXIV], 67-68).

En este listado de características debe destacarse la importancia dada a la juventud del personificador, a su porte, masculinidad, fuerza, esbeltez, de estatura media, pues si era muy alto la gente se burlaría de él diciéndole «removedor de árboles» [cuauhchahchalan] o «recolector de estrellas» [citlalmaololo]. Además, se enfatiza su esbeltez, pues si durante el año de su preparación engordaba, le daban a beber agua mezclada con sal para adelgazar (Sahagún 2002: t. I, lib. II, cap. XXIV, 192).

Este canon de belleza se repite en la descripción de los esclavos que eran escogidos para ser sacrificados durante Panquetzaliztli. Se buscaba uno que fuera muy prudente [cenca mimati], que cantara sumamente bien [cenca huel cuica], de buen semblante [in cualli ixayac], de buen cuerpo [in cualli inacayo], muy limpio [in cenca chipahuac], sin cicatrices ni contusiones ni malformaciones [in acan titiquiltic, xixipuchtic, cocomotztic], sin protuberancias en la frente [cuaxiquipiltic], sin depresiones en la frente [cuatatacaltic], de cuerpo bien proporcionado [ipanoca huel mimati inacayo], delgado [cuillotic], entre otras cualidades (Florentine Codex 1950-1982: lib. IX, cap. X, 46).

Igualmente puede notarse la búsqueda de la perfección física en el representante de Quetzalcóatl de la ciudad de Cholula:

«Cuarenta días antes de este día los mercaderes compraban un indio, sano de pies y manos, sin mácula ni señal ninguna, que ni fuese tuerto, ni con nube en los ojos; no cojo, ni manco, ni contrahecho; no lagañoso, ni baboso, ni desdentado; no había de tener señal ninguna de que hubiese sido descalabrado, ni señal de divieso, ni de bubas, ni de lamparones. En fin, que fuese limpio de toda mácula» (Durán 1967: t. I, cap. VI, $63)$.

Respecto a los atavíos del ixiptla de Tezcatlipoca, los informantes de Sahagún indican que el joven llevaba la cara pintada de color negro. Le ponían plumas en la cabeza de color blanco. Llevaba el cabello hasta la cintura. Le ponían una guirnalda de flores [izquixochitl] y un sartal de las mismas colgado desde el hombro hasta la axila. Llevaba orejeras de oro. Le colgaban una piedra preciosa de color blanco en 
el pecho. Le ponían en los brazos, encima de los codos, unas ajorcas de oro. En las muñecas portaba también unos sartales de piedras preciosas llamadas macuextli. Lo cubrían con una rica manta (como red). Su maxtlatl llevaba diversos adornos, la parte delantera le llegaba hasta las rodillas. Llevaba en las piernas unos cascabeles de oro. Sus sandalias se llamaban ocelunacace, porque «tenía[n] orejas de ocelote» (Sahagún 2002: t. I, lib. II, cap. XXIV, 192).

Veinte días antes de que comenzara Toxcatl, durante el mes Huey Tozoztli, le cambiaban sus ropas por las de un guerrero. Le cortaban la cabellera, le dejaban un mechón sobre la frente y le ataban los cabellos con una borla sobre la corona de la cabeza; a su vez le colocaban otras dos borlas que colgaban de la primera atadura hechas de pluma de garza, oro y tochomitl (estambre teñido de pelo de conejo) que en conjunto se llamaban aztaxelli (Sahagún 2002: t. I, lib. II, cap. XXIV, 193).

Lo casaban con cuatro mujeres que habían sido preparadas para ello durante el año. Cinco días antes de su fiesta, él y sus esposas emprendían una procesión en canoa a lo largo de la cual cantaban y bailaban. En primer lugar llegaban a Tecanman, después al barrio donde se guardaba la escultura de Tezcatlipoca, el tercer día visitaban Tepetzinco, el cuarto llegaban a Tepepulco (Sahagún 2002: t. I, lib. II, cap. XXIV, 193).

El quinto día se dirigían hacia Tlapitzahuayan; allí lo dejaban sus mujeres, solamente lo acompañaban los 8 hombres que habían sido sus acompañantes o guardias (Sahagún 2002: t. I, lib. II, cap. XXIV, 193). Después lo llevaban a un templo llamado Tlacochcalco. Él sólo subía las gradas de la pirámide y rompía las flautas que había estado tocando durante el año en cada escalón. En la cima lo sacrificaban extrayéndole el corazón el cual era ofrecido al sol. A diferencia de otros ixiptlahuan, el cuerpo de Tezcatlipoca no era arrojado escaleras abajo, era bajado con cuidado de la cima del templo, lo decapitaban en el patio y ponían su cabeza en el tzompantli (Florentine Codex 1950-1982: lib. II, cap. VI [XXIV], 70).

En palabras de Carrasco (1991: 50), en Toxcatl se llevaba a cabo el sacrificio perfecto del perfecto ixiptla: la muerte ideal del guerrero enemigo quien había sido aculturado al estilo del ceremonial azteca. De manera que Tezcatlipoca encarnaba la imagen de perfección entre los nahuas, la cual consistía «en una serie de metamorfosis que se [movían] a través del esquema: guerrero-cuerpo perfecto-modelo cultural-dios del tlatoani-potencia sexual-guerrero experimentado-deidad sacrificada» (Carrasco 1991: 50).

\section{Las esposas de Tezcatlipoca y el arreglo femenino}

Al mudar de ropas, el ixiptla se convertía en un yaotequihua, guerrero experimentado o, como lo traduce Molina (2004 [2]: f31r), «capitán de guerra». Este grado militar se le daba a aquél soldado que había destacado matando o tomando cautivos. Le cortaban el cabello y le ponían el tocado de plumas de garza [aztaxelli]. Un privilegio de esta nueva condición era poder tener las mujeres que pudiera sustentar (Durán 1967: t. I, cap. VI, 67; cap. XI, 113-114).

«... los guerreros, los varones, los tequihuaque, los tonsurados, tendrán por nombre cautivadores [tlamanime] [...] Y los que se dediquen a la guerra [yaotequihuaque] 
no tendrán ningún lindero, nada les estorbará, harán cualquier cosa que deseen, se cumplirán todas (sus) ambiciones: en cualquier lugar tomarán a las mujeres, nadie en absoluto los estorbará; todo se hará (su) don; todas las cosas buenas serán suyas, las cosas gustosas, la flor, el tabaco, el canto, cualquier cosa» (Castillo 2001: 98-101).

Este privilegio también lo tenían los cautivos que serían sacrificados: «la víspera de su muerte, velarán toda la noche, comerán, danzarán y se emborracharán; y si acaso alguno quiere acostarse con mujeres, le serán ofrecidas prostitutas, habrá muchísimas mujeres perversas, prostitutas» (Castillo 2001: 100-101).

Como indiqué líneas atrás, al personificador de Tezcatlipoca se le casaba con cuatro mujeres que habían sido preparadas para ser representantes de las diosas Xochiquetzal, Xilonen, Atlatonan y Huixtocihuatl. Esta hierogamia duraba 20 días (Florentine Codex 1950-1982: lib. II, cap. VI [XXIV], 70; Torquemada 1975: t. III, lib. X, cap. XIV, 376).

Igualmente, el personificador de Ixcozauhqui disfrutaba de la compañía femenina durante sus últimos días antes de ser sacrificado. Una ahuiani se volvía su guardia [Auh ce ahuiani, in itepixcauh muchioaya], constantemente le entretenía [muchipa cahuiltia], le alegraba [caahuilia], le bromeaba (buscando seducirlo) [quicamanalhuia], le hacía reír [quihuetzquitia], le hacía cosquillas [quiquequeloa], se complacía en su cuello [iquechtlan aaqui], le abrazaba [quiquechnahua], le espulgaba [caatemia], le peinaba [quitzitzicuahuazhuia], le arreglaba el cabello [quipepepetla], disipaba su tristeza [quitlaoculpopoloa] (Florentine Codex 1950-1982: lib. II, cap. XXXVIII, 169) ${ }^{12}$.

Además de permitirles tener todas las mujeres que pudieran sustentar, a los guerreros les estaba autorizado bailar con las ahuianime, adular a las mujeres y coquetear con ellas públicamente; de esta manera subrayaban sus privilegios (Durán 1967: t. I, cap. XXI, 195). Ejemplo de ello sucedía durante la fiesta Huey Tecuilhuitl:

«Todos estos ocho días bailaban y danzaban, haciendo areito hombres y mujeres, todos juntos, todos muy ataviados con ricas vestiduras y joyas. Las mujeres traían los cabellos sueltos. Andaban en cabello, bailando y cantando con los hombres [...] En este baile $\mathrm{o}$ areito andaban trabados de las manos, o abrazados, el brazo del uno asido del cuerpo, como abrazado, y el otro asimismo del otro, hombres y mujeres [...] (Sahagún 2002: t. I, lib. II, cap. VIII, 148) [...] Estos que hacían este areito era toda gente escogida, capitanes y otros valientes hombres ejercitados en las cosas de la guerra» (Sahagún 2002: t. I, lib. II, cap. XXVII, 214).

Diariamente, en el cuicacalli los guerreros bailaban con las mujeres; en contraste, a los jóvenes les tenían prohibido acercarse a ellas. Señala Durán (1967: t. I, cap. XXI, 194-195) «Aquel patio se henchía de rameras, que las había muchas y muy desvergonzadas». Los guerreros observaban si alguna mujer les prestaba atención, la llamaban, le tomaban de la mano, bailaban con ella y pasaban toda la tarde con aquella mujer. Le pintaban los labios y las mejillas, le ponían plumas en la cabeza y joyas al cuello.

12 Sobre el papel de la prostitución en la sociedad nahua véanse López 2011, 2012; Moreno 1966; Olivier 2002b; Szoblik 2008. 
Los bailes, el coqueteo y el arreglo de las mujeres nos invita a comentar cómo era el maquillaje femenino y otros atributos relacionados con la belleza y el erotismo.

El amarillo era el color distintivo de la feminidad. Tanto las mujeres nobles como las ahuianime usaban maquillaje de este color en la cara, y los dientes se los pintaban con grana cochinilla: rojo (Florentine Codex 1950-1982, lib. VIII, cap. XV, 47-48; lib. X, cap. XV, 55). La distinción que señala Galdemar (1992: 151-152) era la proveniencia del color amarillo. En las primeras era un amarillo de origen mineral (ocre amarillo) (tecozahuitl) y en las segundas era de origen animal (axin) $)^{13}$. En ambos casos, éste indicaba que la mujer estaba en disposición de ser compañera, en el sentido de poder entablar relaciones sexuales con el marido o el amante; esto último para las prostitutas.

Aunque se les permitía a las mujeres nobles utilizar maquillaje para «hermosearse», se les exhortaba a cuidar su comportamiento: así no deberían de imitar a las prostitutas. Les desaconsejaban su uso pues este denotaba perversión y era dominio de las malas mujeres, las disolutas, las llamadas ahuianime (Florentine Codex 19501982: lib. VI, cap. XIX, 101). Los informantes de Sahagún describen a estas mujeres de la siguiente manera:

«Rostro vanidosillo, excesivamente compuesta, demasiado compuesta $[\ldots]$ se ensa$\mathrm{ya}^{14}$, se mueve lujuriosamente [...] se atavía, se engalana, actúa vanidosamente, se yergue florida, se yergue excesivamente ataviada, se adorna excesivamente [...] se hace brillante con ungüento, se hace muy brillante con ungüento [...] se afeita, se afeita con exceso, se pinta el rostro, se pinta las mejillas, se oscurece los dientes, se pone grana cochinilla en los dientes, sus cabellos caen sueltos, peinados a la mitad, se hace cuernos con sus cabellos. Se contonea, anda con desvergüenza, anda levantando la cabeza, anda moviendo la cabeza con altanería [...] anda paseando, anda echándose encima, se echa encima, se burla, anda burlándose, anda contenta, va de un lado a otro, anda de un lado a otro [...] hace señas a la gente, cierra el ojo a la gente, cierra el ojo a la gente, guiña el ojo a la gente, llama a la gente con la mano, vuelve el rostro, ríe, anda riendo» (López Austin 1996 [1980]: II, 276).

De manera que el arreglo personal excesivo se vincula con un comportamiento reprobado socialmente. Asimismo, se menciona que mujeres de otros grupos étnicos lo empleaban. Las mujeres otomíes se pintaban el rostro con la piedra llamada tecozahuitl y se oscurecían los dientes (Florentine Codex 1950-1982: lib. X, cap. XXIX, 179). En tanto, las mujeres mazahuas de edad avanzada se pintaban sus caras con amarillo ocre y con rojo, inclusive se adornaban los brazos y las piernas con plumas (Florentine Codex 1950-1982: lib. X, cap. XXIX, 183). El adorno de plumas rojas en piernas y brazos también lo empleaban las muchachas otomíes. Estas últimas no respetaban las formas de embellecerse propias de los pipiltin, se pintaban y ornamentaban el cuerpo (Florentine Codex 1950-1982: lib. X, cap. XXIX, 178-179).

13 Dupey $(2010: 84,99)$ propone que el término tecozahuitl es un genérico para la categoría de pigmentos color amarillo obtenidos por la combinación de tinta de base mineral y un colorante vegetal. En tanto, el axin era «una grasa amarilla obtenida a partir del insecto coccus axinus».

14 «En el sentido de mostrarse remedando el acto sexual» (López Austin 1996 [1980], II: 275, nota 61). 
Figura 7: Mujeres pipiltin con diferentes peinados (Códice Florentino 1979: t. II, lib. VIII, cap. XV, f. 31r).

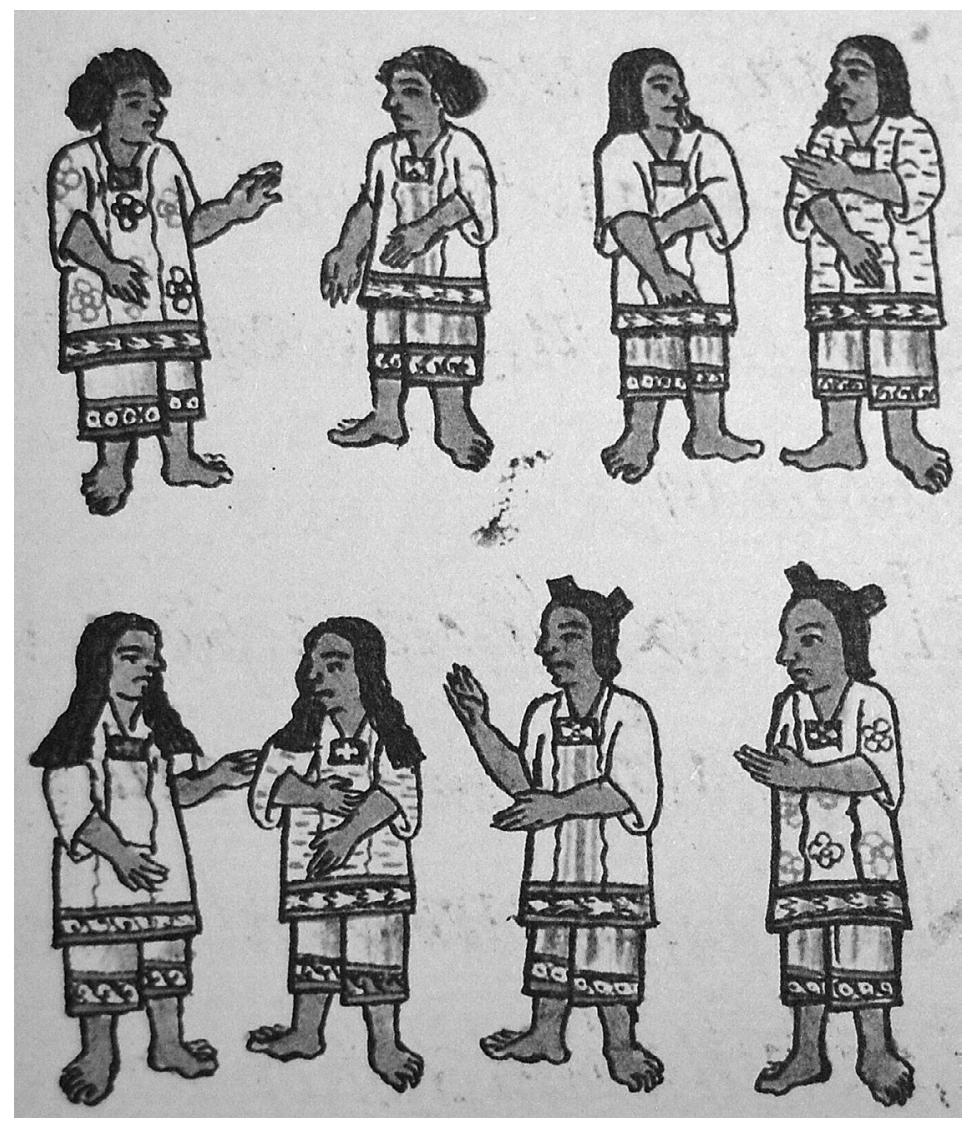

Las mujeres nobles, además de maquillarse el rostro con tecozahuitt $l^{15}$ y pintarse los dientes con cochinilla, se teñían el cabello de color índigo (morado/azul) con un barro negro llamado palli o con la planta llamada xiuhquilitl. En sus manos y cuello pintaban diseños, al igual que en sus vientres y pecho (Florentine Codex 1950-1982: lib. VIII, cap. XV, 47-48) ${ }^{16}$.

Para el cuidado del cabello utilizaban distintas preparaciones que mantenían su suavidad, color y brillo. Una solución efectiva para darle sedosidad era la infusión con semillas de chatalhuic. Para darle color y brillo usaban el aceite espeso de las semillas del árbol tzopilotl tzontecomatl (Swietenia mahagoni) (Flores y Troncoso 1992: 426-427; Sahagún 2002: t. II, lib. VIII, cap. XV: 763; Florentine Codex 19501982: lib. VIII, cap. XV, 47-48).

Respecto al peinado, algunas traían los cabellos sueltos y largos hasta la cintura o hasta los hombros, otras lo traían hasta la espalda. Unas gustaban cortar una parte

15 En los Primeros Memoriales (Sahagún 1997, cap. III: 56r, 205-206 citado por Dupey 2010: 106) se menciona que el rostro además de estar pintado con amarillo -aunque no únicamente de ese color- tenía motivos en color rojo.

16 La xiuhquilitl pitzahuac (Indigofera añil Linn.) y la xiuhquilitl patlahuac (Calliandra gracilis, Klotzsch) producían un tono azul de acuerdo con Dibble y Anderson (Florentine Codex 1950-1982: lib. VIII, 48 nota 3). 
hasta la sien y oreja y otra parte dejarla larga. Otras se trasquilaban la cabeza y otras llevaban el peinado que se realizaba partiendo la cabellera en dos mechones que se cruzaban en la nuca y eran llevados de forma torcida o trenzada alrededor de la cabeza, hacia la frente, para terminar en dos puntas levantadas en forma de cornezuelos (Sahagún 2002: t. II, lib. VIII, cap. XV, 763; Florentine Codex 1950-1982: lib. VIII, cap. XVI, 47-48) (Figura 7).

De manera que a las mujeres nahuas les gustaba utilizar colores brillantes, así lucían rojo en los dientes, índigo en el cabello, rojo y amarillo en el rostro (Sahagún 2002: t. II, lib. VIII, cap. XV, 763; Florentine Codex 1950-1982: lib. VIII, cap. XVI, 47-48). En la estética nahua la combinación de múltiples colores además de brillantes constituía la base de su estética, no sólo en los rostros y vestimentas de las personas, también en las fiestas y creaciones artísticas (Dupey 2010: 106).

Así, el maquillaje servía para embellecer, pero las mujeres no debían rebasar la delgada línea entre la belleza y la vanidad, ni caer en el comportamiento de las prostitutas que con sus encantos buscaban seducir. Era un marcador de prestigio entre la clase noble y el pueblo, además de ser -en algunos contextos- un marcador de rito de paso, el matrimonio.

\section{Conclusiones}

De acuerdo con Eco (2007a: 8) lo bello es una adjetivo empleado para calificar una cosa que nos gusta. En diferentes culturas y épocas se ha vinculado lo bello con lo bueno; de hecho, una cosa que consideramos buena nos gusta y además, deseamos poseerla. En este sentido, en la cultura náhuatl la belleza iba unida a la virtud. Así, bello designaba además de características estéticas, cualidades morales.

El ideal nahua de perfección se resume en el difrasismo «in quallotl in yecyotl». De acuerdo con León-Portilla (2006: 235, 387) significa «la conveniencia, la rectitud». Cuallotl en particular es un concepto que significa «la cualidad de todo aquello que es comible», es decir, «de lo que puede ser asimilado por el propio yo, o le es conveniente». Molina (2004 [1]: f. 20v) traduce cuallotl como bondad. A su vez, huel cuallotl significa belleza, elegancia (Wimmer 2004: entrada cuallotl). Por su parte, yecyotl deriva de la palabra yectli «recto». Este término abarca una serie de significados que incluyen, bien, bueno, derecho, hermoso, recto (GDN 2012: entrada yectli, tomado de Carochi 1645).

He expuesto las características de los cuerpos bellos, deseables, pero a la par se esperaba de estos individuos un comportamiento ejemplar. De hecho, los sujetos sobresalientes en las fiestas pertenecían en muchos casos a la nobleza, clase social a la que se le exigía una conducta intachable y de moderación en todo. En otros casos, eran personas que tenían un físico sobresaliente y por ello eran escogidos y entrenados para personificar a los dioses.

Una persona atractiva nacía con ciertas características descritas en los documentos etnohistóricos y palpables en la escultura. Asimismo, los que serían ixiptlahuan debían desarrollar determinadas habilidades como la oratoria, la habilidad musical, el baile, el canto y oler agradablemente. Este perfil estético está circunscrito a los valores del grupo en cuestión, a sus ideales, a sus roles de ideología de género, a su sistema de clases sociales, a sus supuestos de la masculinidad, de la feminidad. 
Las ideas estéticas las podemos leer en la literatura, estudiar los gustos en la moda y las costumbres, me refiero a la vestimenta y el maquillaje, a la forma correcta de comportarse, y también extraerlas de las obras de arte. Como se estudió, en la escultura mexica están contenidas proposiciones estéticas, las cuales fueron mi punto de partida para reconstruir el perfil de belleza y erótica nahua. Un cuerpo alcanza su esplendor en la etapa de la juventud pues tiene la madurez y fuerza para realizar las diferentes actividades que requiere la comunidad; una de ellas es la reproducción. En esa edad, el cuerpo se encuentra en el momento cumbre, pues goza de salud. Fiel reflejo de ello lo encontramos en la escultura náhuatl.

Asimismo, un cuerpo esbelto y fuerte es el deseable en ambos géneros. La gordura asociada a la glotonería estaba mal vista, pues impediría que realizaran sus labores de manera correcta y con la energía necesaria. Recordemos que todas las actividades que llevaban a cabo, tanto fuera como en el interior del hogar, requerían de una fuerza física y resistencia considerables: agricultura, cerámica, guerra, cuidado de los hijos, de los ancianos y atención de los animales, etc.

He destacado que la belleza en la antigua cultura nahua iba unida a la virtud. Pero también en su ideal estético estaban incorporados los conceptos de juventud, fuerza y salud. En contraparte, la fealdad se vinculaba con el deterioro del cuerpo: degeneración, envejecimiento y enfermedad.

En palabras de Nietzsche en el Crepúsculo de los ídolos: «Lo feo se entiende como señal y síntoma de degeneración... Todo indicio de agotamiento, de pesadez, de senilidad, de fatiga, toda especie de falta de libertad, en forma de convulsión o parálisis [...] ¿a quién odia aquí el hombre? No hay duda: odia la decadencia de su tipo» (Eco 2007b: 15). El deterioro del cuerpo y de las capacidades del mismo son dos cosas que teme el hombre. El miedo a envejecer agobia a la mente humana.

Aunque se menciona que los ancianos entre los antiguos nahuas gozaban de una posición privilegiada, existen datos que matizan esta afirmación (López Austin 1996 [1980]: I, 327-328; II, 272-273). En los Anales de Cuauhtitlan (1992: 31-32), Tezcatlipoca se presenta en el palacio de Quetzalcóatl en el cuerpo de un telpochtli. Le muestra su cuerpo en un espejo y éste se espanta al ver su rostro hinchado y con los ojos hundidos. Los dioses se presentan en una oposición. El cuerpo deteriorado de Quetzalcóatl probablemente apunta a sus transgresiones sexuales. Cabe señalar que la inmoderación sexual causaba envejecimiento (Florentine Codex 1950-1982: lib. VI, 116; Olivier 2004b: 167).

Los modelos de belleza y juventud eran Tezcatlipoca y Xochiquetzal. Telpochtli «joven» era uno de los nombres del dios. Bajo esta advocación era el dios protector de los telpochcalli, «casa de jóvenes», centro educativo para los futuros guerreros mexicas (Sahagún 1985: 22-23, Durán 1967: t. I, cap. V, 49). En tanto, uno de los nombres de Xochiquetzal era Ichpochtli «la joven» (Códice Telleriano-Remensis 1964: 172-173, XI:lám. 6r). Estos dioses se presentan como amantes en distintas fuentes y se ostentan como los paradigmas de belleza, sexualidad y erotismo.

AGRadecimientos: La elaboración de este artículo fue posible gracias al apoyo que me otorgó la Coordinación de Humanidades de la UNAM, en el marco del programa de Becas Posdoctorales en la UNAM. 


\section{Referencias bibliográficas}

Aguilera, Carmen

1977 El arte oficial tenochca y su significación social. México: Instituto de Investigaciones Estéticas. UNAM.

Alberoni, Francesco

2006 El erotismo. Barcelona: Editorial Gedisa.

Alvarado Tezozomoc, Fernando

1998 Crónica Mexicayotl, traducción de Adrián León. México: Instituto de Investigaciones Históricas. UNAM.

Anales de Cuauhtitlan

1992 Códice Chimalpopoca, The Text in Nahuatl with a Glossary and Grammatical Notes, John Bierhorst, ed. Tucson-Londres: University of Arizona Press.

Arqueología Mexicana

2003 Arqueología Mexicana. Edición especial 13. Aztecas.

BATAILLE, Georges

1979 El erotismo. Barcelona: Tusquets.

CARrasco, David

1991 «The Sacrifice of Tezcatlipoca: To Change Place», en Aztec Ceremonial Landscapes, David Carrasco, ed., pp. 31-57. Niwot: University Press of Colorado.

CAstillo, Cristóbal del

2001 Historia de la venida de los mexicanos y otros pueblos e Historia de la conquista. México: Consejo Nacional para la Cultura y las Artes.

Clendinnen, Inga

1998 Los aztecas. Una interpretación. México: Editorial Nueva Imagen.

CóDICE Borgia

1993 Los templos del cielo y de la oscuridad, oráculos y liturgia: libro explicativo del llamado Códice Borgia, introducción y explicación de Ferdinand Anders, Maarten Jansen y Luis Reyes, facsímil. Graz y México: Akademische Druck Verlagsanstalt Graz y Fondo de Cultura Económica.

CóDice Telleriano-Remensis

1964 «Códice Telleriano-Remensis» en Antigüedades de México, basadas en la recopilación de Lord Kingsborough, José Corona Núñez, ed., v. I, pp. 151-337. México: Secretaría de Hacienda y Crédito Público.

DuPEy García, Élodie

2010 Les couleurs dans les pratiques et les représentations des Nahuas du Mexique central (XIVe-XVIe siècles). Tesis de doctorado. École Pratique des Hautes Etudes, Section des Sciences Religieuses. Paris.

DURÁN, fray Diego

1967 Historia de las Indias de Nueva España e islas de tierra firme, edición de Ángel María Garibay K., v. I. México: Editorial Porrúa.

Eco, Umberto

2007a Historia de la belleza. Barcelona: Lumen. 
2007b Historia de la fealdad. Barcelona: Lumen.

EL IMPERIO AZTECA

2004 El imperio Azteca. Catálogo de exposición, Felipe Solís Olguín, curador. México: Grupo Financiero Banamex.

Florentine Codex

Véase SAHAGÚN 1950-1982.

Flores y Troncoso, Francisco de Asís

1992 Historia de la medicina en México desde la época de los indios hasta el presente. México: Instituto Mexicano del Seguro Social.

FuENTE, Beatriz de la

2004 «Trazos de una identidad», en El Imperio Azteca, Felipe Solís Olguín, curador, pp. 38-52. México: Grupo Financiero Banamex.

GALDEMAR, Edith

1992 «Peintures faciales de la femme mexica: système chromatique des cosmétiques». Estudios de Cultura Náhuatl 22: 143-165.

GARIBAY, Ángel María

2000 Historia de la literatura náhuatl, prólogo de Miguel León-Portilla. México: Editorial Porrúa.

GENDRop, Paul e Iñaki DíAz BALERDI

1994 Escultura azteca: una aproximación a su estética. México: Editorial Trillas.

Gran Diccionario NáHuATl (GDN)

2012 México: UNAM. http://www.gdn.unam.mx (06.07.2014).

HISTORIA TOLTECA-CHICHIMECA

1989 Historia tolteca-chichimeca. Paul Kirchhoff, Lina Odena y Luis Reyes, eds. México: CIESAS, FCE, Gobierno del Estado de Puebla.

LEÓN-Portilla, Miguel

1959 «La historia del Tohuenyo -narración erótica náhuatl-». Estudios de Cultura Náhuatl 1: 95-112.

2006 La filosofía náhuatl estudiada en sus fuentes. México: Instituto de Investigaciones Históricas. UNAM.

López Austin, Alfredo

1996 Cuerpo humano e ideología. Las concepciones de los antiguos nahuas [1980]. México: Instituto de Investigaciones Antropológicas. UNAM.

1998 Hombre-dios: religión y política en el mundo náhuatl. México: Instituto de Investigaciones Históricas. UNAM.

\section{LóPEZ HERNÁNDEZ, Miriam}

2011 «Discursos sobre la prostitución entre los mexicas», en Avances de las mujeres en las ciencias, las humanidades y todas las disciplinas, Leticia Romero Chumacero, ed., pp. 401-417. México: Universidad Autónoma Metropolitana.

2012 «Ahuianime: las seductoras del mundo nahua prehispánico». Revista Española de Antropología Americana 42 (2): 401-423.

2013 Sexualidad entre los antiguos nahuas. Análisis de las representaciones, discursos y prácticas sexuales. Tesis de doctorado. México: Instituto de Investigaciones Antropológicas. UNAM. 
LóPez LuJán, Leonardo y Laura FILLOY NADAL

2012 «La Señora de Chalma». Arqueología Mexicana 117: 71-77.

Molina, fray Alonso de

2004 Vocabulario en lengua castellana y mexicana y mexicana y castellana, estudio de Miguel León-Portilla. México: Editorial Porrúa.

Moreno De Los Arcos, Roberto

1966 «Las ahuianime». Historia Nueva 1: 13-31.

OLIVIER, Guilhem

2002a «The Hidden King and the Broken Flutes: the Mythical and Royal Dimension of Tezcatlipoca's Feast in Toxcatl», en Representing Ritual: Performance, Text and Image in the Work of Sahagún, Eloise Quiñones, coord., pp. 107-142. Niwat: University of Colorado Press.

2002b «Entre diosas y prostitutas. Las alegres del mundo mesoamericano», en Placer, dinero y pecado. Historia de la prostitución en Colombia, Aída Martínez y Pablo Rodríguez, eds. y compls., pp. 17-37. Bogotá: Editora Aguilar.

2004a Tezcatlipoca. Burlas y metamorfosis de un dios azteca. México: Fondo de Cultura Económica.

2004b «También pasan los años por los dioses: niñez, juventud y vejez en la cosmovisión mesoamericana», en El historiador frente a la historia: El tiempo en Mesoamérica, Virginia Guedea, coord., pp. 149-180. México: Instituto de Investigaciones Históricas. UNAM.

Piho Lange, Virve

1973 El peinado entre los mexicas: formas y significados. Tesis de Doctorado. Facultad de Filosofía y Letras. UNAM. México.

POMAR, Juan Bautista

2000 «Relación de Tezcoco», en Poesía náhuatl I: Romances de los señores de la Nueva España, Ángel Ma Garibay K., ed., pp. 149-219. México: Instituto de Investigaciones Históricas. UNAM.

ReAl ACADEMia EsPañola

2014 Diccionario de la Lengua Española (23 ${ }^{\mathrm{a}}$ ed.). http://www.rae.es/rae.html (11.08.2014).

SAHAGúN, fray Bernardino de

1950-82 Florentine Codex. General History of the Things of New Spain, Fray Bernardino de Sahagún, libs. II, III, VI, VIII, IX, X, XII, Charles E. Dibble y Arthur J.O. Anderson, eds. Santa Fe: School of American Research, University of Utah.

1979 Códice Florentino. Manuscrito 218-20 de la Colección Palatina de la Biblioteca Medicea Laurenziana, tomo II. México: Secretaría de Gobernación, Archivo General de la Nación.

1985 Educación mexica. Antología de textos sahaguntinos, edición y traducción por Alfredo López Austin. México: Instituto de Investigaciones Antropológicas. UNAM.

2002 Historia general de las cosas de Nueva España, tomos I, II, edición de Alfredo López Austin y Josefina García Quintana. México: Consejo Nacional para la Cultura y las Artes.

SELER, Eduard

1980 Comentarios al Códice Borgia, tomo 2. México: Fondo de Cultura Económica. 
Solares, Blanca

2007 Madre terrible: la diosa en la religión del México antiguo. México: Anthropos Editorial, Centro Regional de Investigaciones Multidisciplinarias, Instituto de Investigaciones Filológicas, Programa Universitario de Estudios de Género. UNAM.

Solís Olguín, Felipe

1985 «Arte, Estado y sociedad. La escultura antropomorfa de México-Tenochtitlan», en Mesoamérica y el centro de México, Jesús Monjarás-Ruiz, Rosa Brambila y Emma Pérez-Rocha, comps., pp. 393-432. México: Instituto Nacional de Antropología e Historia.

1991 Gloria y fama mexica. México: Smurfit Cartón y Papel de México.

2004 «Orígenes y formas del arte en el imperio azteca», en El Imperio Azteca, Felipe Solís Olguín, curador, pp. 100-102. México: Grupo Financiero Banamex.

STRESSER-PÉAN, Guy

1971 «Ancient Sources of the Huasteca», en Handbook of Middle American Indians, vol. 11, pp. 582-602. Austin: University of Texas Press.

SzoBLIK, Katarzyna

2008 «La ahuiani, ¿Flor preciosa o mensajera del diablo? La visión de las ahuianime en las fuentes indígenas y cristianas». Itinerarios 8: 197-214.

Toriz Proenza, Martha Julia

2011 Teatralidad y poder en el México antiguo. La fiesta Tóxcatl celebrada por los mexicas. México: Instituto Nacional de Bellas Artes.

TORquemadA, fray Juan de

1975 Monarquía Indiana de los veinte y un libros rituales y monarquía indiana, con el origen y guerras de los indios occidentales, de sus poblazones, descubrimiento, conquista, conversión y otras cosas maravillosas de la mesma tierra, tomos III, IV, Miguel León-Portilla, ed. México: Instituto de Investigaciones Históricas. UNAM.

WIMMER, Alexis

2004 «Diccionario de náhuatl clásico» en CEN (Compendio Enciclopédico del Náhuatl), CD-ROM. México: Instituto Nacional de Antropología e Historia. 